\title{
PEMBERDAYAAN UNTUK MENINGKATKAN KOMPETENSI PEJABAT STRUKTURAL PEMERINTAH: Kasus di Bidang Kepegawaian di Provinsi DKI Jakarta dan Provinsi DI Yogyakarta
}

\author{
(EMPOWERMENT OF THE STRUCTURAL GOVERNMENT \\ OFFICIALS (SGO) ON THEIR COMPETENCE:
} Case Studi of the SGO in the Provinces dan Jakarta and Yogyakarta)

\author{
Djoko Sutrisno, Sumardjo, Pang S. Asngari, Soedijanto Padmowihardjo \\ dan Prabowo Tjitropranoto
}

\begin{abstract}
The civil service management had to change its paradigm in appointing the structural goverment officials (SGO)'s so far the work achievement of goverment structural officials was still low. In conjunction with this, the objectives of this research were: (1) To evaluate the level of empowerment, internal organization characteristics, motivation and competency of SGO; (2) To determine the factors that influence the empowerment, competence and motivation of SGO; and (3) To formulate the model for increasing the structural geverment officials (SGO) competency. This research was accomphlished in DKI Jakarta and DI Yogyakarta. This research was a census, 163 government structural officials were interviewed. The research results pointed out that: (1) The levels of empowerment, attitudes, motivation and competency of every officials interviewed were good. Additionally, their nonformal education and organization technology was also good. (2) The non formal education, attitudes and mastering of organization technology were related to the SGO empowerment; (3) The empowerment and the motivation of SGO were significantly related to their competencies; (4) The SGO empowerment was related to the SGO motivation. Based upon these fundings, it could be concluced that all factors investigated were related to the empowerment, and on the other hand the empowerment was related to the SGO motivation and competency.
\end{abstract}

Key words: Empowerment, internal characteristics of organization, motivation and competency.

\section{PENDAHULUAN}

Globalisasi telah membawa dampak luas, dunia menjadi semakin lebih terbuka. negara-negara menjadi saling terhubungkan dan perekonomiannya ditandai oleh saling ketergantungan. Gejala globalisasi mendorong timbulnya kompetisi yang tajam antar Negara.
Untuk mengantisipasi perubahan-perubahan tersebut, Pemerintah telah menggulirkan reformasi di sektor publik, dan pelaksanaan perubahan tersebut menurut Kristiadi (1997: 33) dilakukan melalui kebijakan deregulasi, debirokratisasi dan desentralisasi. Dalam kaitan ini, aparatur di daerah perlu dimotivasi dan diberdayakan, untuk 
menyadari peran penting dan tanggung jawabnya terhadap kelancaran jalannya pelaksanaan setiap kebijaksanaan pemerintah yang telah digariskan. Dengan menyadari perannya dalam pembangunan ekonomi di daerahnya, yang merupakan subsistem dari pembangunan nasional, maka akan tumbuh kesadaran untuk berinisiatif meningkatkan efisiensi dan efektivitas aparaturnya, dengan menghilangkan atau memperbaiki peraturanperaturan yang berlebihan, dan mengurangi campur tangan birokrasi yang tidak diperlukan dalam pembangunan ekonomi di wilayahnya.

Dalam pembangunan negara, kedudukan dan peranan Pegawai Negeri Sipil (PNS) strategis dan menentukan, karena PNS sebagai unsur aparatur negara yang secara riil menyelenggarakan tugas umum pemerintahan dan tugas pembangunan dalam rangka mencapai tujuan nasional. Namun kenyataannya dalam pembangunan daerah masih terdapat masalah-masalah yang belum dapat dipecahkan, antara lain: ketimpangan pertumbuhan ekonomi dan pembangunan daerah antarprovinsi, antarkota, antarkabupaten dan antardesa; meningkat dan meluasnya pengangguran; membengkaknya jumlah penduduk miskin dan sebagainya. Masalah-masalah pembangunan tersebut tampak terkait dengan kompetensi PNS. Dalam posisinya yang demikian, tampaknya PNS menjadi salah satu kunci dalam menentukan efektivitas pembangunan, sehingga menarik untuk diteliti bagaimana kompetensi PNS. Dalam organisasi pemerintah, kedudukan pejabat struktural menjadi kunci dalam pembangunan, karena semua aktivitas yang berkaitan dengan kebijakan pembangunan, mulai dari penyusunan program sampai pelaksanaan kegiatan pembangunan ditentukan Pejabat Struktural Kepegawaian Pemerintah (PSKP), sehingga bagaimana kompetensi Pejabat Struktural Kepegawaian Pemerintah (PSKP), apakah telah memiliki kompetensi sesuai dengan yang dipersyaratkan untuk jabatan strukturalnya perlu dipahami. Oleh karena itu, upaya peningkatan kompetensi PSKP perlu dilakukan secara terencana dan terarah. Untuk mewujudkan PSKP yang demikian, diperlukan pembinaan secara tepat, selain melalui proses manajeman PNS yang berbasis kompetensi, juga melalui pendidikan luar sekolah (penyuluhan bagi PSKP).

Hasil penelitian terbaru dari Price Waterhouse Copers bulan Oktober 2001 menunjukkan (Budihardjo, 2002:141), bahwa kinerja tata pemerintahan yang berarti juga kinerja PNS di Indonesia merupakan yang terburuk, peringkatnya lebih rendah dibanding dengan Cina, India, dan Thailand. Kelemahan tersebut, menuntut pemerintah berupaya keras mengubah visi PNS khususnya PSKP sesuai tuntutan reformasi, yaitu dari yang semula kurang profesional dalam memberikan pelayanan pada publik, menjadi profesional. Ciri-ciri profesional adalah memiliki wawasan yang luas dan dapat memandang masa depan, memiliki kompetensi di bidangnya, memiliki jiwa berkompetisi/ bersaing secara jujur dan sportif, serta menjujung tinggi etika profesi (Maarif, 2002: 60). Untuk meningkatkan profesionalisme yang berbasis kompetensi, pemerintah telah mengeluarkan Undangundang Nomor 43 Tahun 1999, Hal ini sebagai langkah mereformasi Undang-undang Nomor 8 Tahun 1974 yang dipandang sudah tidak sesuai lagi. Undang-undang Nomor 43 tersebut pada dasarnya berisi kebijakan manajemen kepegawaian PNS dengan paradigma baru, yang substansinya dijiwai oleh semangat desentralisasi kewenangan kepegawaian, baik kepada instansi pusat (Departemen/ Lembaga Non Departemen) maupun kepada Pemerintah Daerah Provinsi/ Kabupaten/ Kota.

Dalam salah satu ketentuannya antara lain disebutkan, bahwa pengangkatan PNS dalam suatu jabatan dilaksanakan berdasarkan prinsip profesionalisme sesuai dengan kompetensi, prestasi kerja, dan jenjang pangkat yang ditetapkan untuk jabatan itu serta syarat obyektif lainnya tanpa membedakan jenis kelamin, suku, agama, ras, atau golongan. Etika profesional yang merupakan nilai-nilai dasar modern, pada umumnya mempunyai ciri-ciri (Mas'ud, 2002: 62, 63): (1) efisien, bekerja dengan baik, 
pemborosan kecil; (2) rajin, penuh perhatian dan sibuk; (3) ketertiban; (4) ketepatan waktu; (5) kecermatan, kesederhanaan; (6) Kejujuran yang ketat, kejujuran yang cermat yang berakibat dalam jangka panjang meningkatkan efisiensi; dan lainnya. (7) Rasionalitas dalam keputusan-keputusan tindakan, membebaskan diri dari ketergantungan kebiasaan yang statis, kesetiaan kelompok, serta kesayangan dan kepercayaan kesayangan yang tidak rasional atau fanatisme buta dan berprasangka; (8) Siap siaga akan perubahan-perubahan; dan lainnya. Namun, nilai-nilai modern tersebut belum sepenuhnya dimiliki oleh para PSKP. Hal ini tampak dari hasil penelitian, yang menyatakan pada umumnya organisasi pemerintah di manapun sering menghadapi tiga masalah yakni : kurang efektif, kurang efisien dan mutu pelayanan yang kurang (Departemen Tenaga Kerja dan Universitas Padjadjaran, 1987:43).

Dalam melaksanakan manajemen kepegawaian PNS, tingkat kompetensi PSKP Pemerintah Daerah Provinsi/ Kabupaten/ Kota masih menunjukkan gejala-gejala belum baik, yaitu belum sesuai dengan persyaratan yang ditentukan untuk jabatan strukturalnya. Sedangkan faktor-faktor yang mempengaruhi kompetensi belum diketahui. Oleh karena itu, masalah dalam penelitian ini adalah: (1) Faktor-faktor manakah yang cenderung lebih berpengaruh terhadap kompetensi PSKP?; (2) Bagaimanakah keterkaitan antara faktorfaktor pemberdayaan, motivasi dan karakteristik internal organisasi?

Berdasarkan uraian di atas, maka tujuan penelitian ini adalah: (1) mengkaji tingkat pemberdayaan PSKP, tingkat karakteristik internal organisasi (pendidikan non formal, masa kerja, sikap dan teknologi organisasi), tingkat motivasi PSKP, dan tingkat kompetensi PSKP; (2) menjelaskan keterkaitan antara faktor-faktor faktor-faktor pemberdayaan, motivasi dan karakteristik internal orgnisasi; (3) menetapkan faktorfaktor determinan yang mempengaruhi kompetensi PSKP; dan (4) merumuskan model pemberdayaan PSKP dalam upaya peningkatan kompetensi.

\section{Metode Penelitian}

\section{Populasi dan Sampel}

Populasi penelitian adalah semua pejabat struktural yang tugasnya melaksanakan manajemen kepegawaian PNS, dan bekerja di lingkungan Kantor Regional BKN; Biro Kepegawaian Provinsi; Kantor BKD Provinsi, Kabupaten dan Kota, Kantor BKD dan Diklat Kabupaten; Bagian Kepegawaian Kabupaten dan Kota yang ada di Provinsi Daerah Khusus Ibu Kota Jakarta dan Provinsi Daerah Istimewa Yogyakarta.

Penelitian dilakukan terhadap semua pejabat struktural Eselon IV, Eselon III, Eselon II yang tugasnya melaksanakan manajemen PNS di Provinsi DKI Jakarta dan Provinsi D I Yogyakarta. Jumlah responden 163 orang, dan jumlah instansi pemerintah yang menjadi lokasi penelitian ada 14 instansi, yakni tujuh instansi di masingmasing provinsi.

\section{Data dan Instrumentasi}

Menurut Black dan Champion (1999: 93) ada dua perangkat penting yang menjadi perhatian para ilmuwan sosial, yakni kesahihan (validity) dan keterandalan (reliability). Cara mengujinya mengacu Singarimbun dan Effendi ( 1995: 137 ), dan Sevilla, Ochave, Punsalan, Regala, dan Uriarte (1993: 189) dengan menghitung korelasi masing-masing pernyataan dengan skor total, dan hasilnya: (1) variabel kompetensi PSKP kisaran koefisien korelasi: $0.61-0.91$; (2) variabel pemberdayaan PSKP kisaran koefisien korelasi $0.60-0.87$; (3) variabel karakteristik internal organisasi kisaran koefisien korelasi 0.63 - 0.94; (4) variabel motivasi PSKP kisaran koefisien korelasi: $0.75-0.88$.

Reliabilitas diukur dari koefisien korelasi belahan pertama dengan belahan kedua, dengan tingkat signifikansi 5\% dan hasilnya : (1) pemberdayaan PSKP koefisien korelasi Spearman Brown $=0.97$; (2) karakteristik internal organisasi koefisien korelasi Spearman Brown = 0.79, (3) motivasi 
PSKP koefisien korelasi Spearman Brown = 0.75; (4) kompetensi PSKP koefisien korelasi Spearman Brown $=0.97$. Data dikumpulkan dengan wawancara menggunakan kuesioner.

\section{$\underline{\text { Analisis Data }}$}

Metode untuk menganalisis pengaruh beberapa variabel bebas terhadap variabel tak bebas adalah korelasi ganda $r$ (multiple $\mathrm{R}$ ), koefisien determinasi ( $\mathrm{R}$ square), analisis regresi berganda dan analisis path/ jalur (Kerlinger, 2000:990), (Sumardjo, 1999 : 139 ), (Cohen dan Cohen, 1983 : 100), (Ferdinand, 2000:3), dan (Wibowo, 2004 : 1).

\section{Hasil dan Pembahasan}

(1) Usaha-usaha dan Tingkat Pemberdayaan PSKP

Dari analisis data diperoleh hasil, tentang usaha dan tingkat pemberdayaan PSKP seperti disajikan pada Tabel 1.

\section{(2) Tingkat Kompetensi PSKP}

Dari analisis data diperoleh hasil bahwa kategori penilaian terhadap kompetensi adalah sebagaimana tersebut pada Tabel 2.

Tabel 1. Usaha-Usaha dan Hasil Penilaian (skor) terhadap Variabel Pemberdayaan PSKP

\begin{tabular}{|l|c|c|c|c|}
\hline $\begin{array}{c}\text { Variabel dan Usaha- } \\
\text { Usaha }\end{array}$ & $\begin{array}{c}\text { Provinsi } \\
\text { DKI }\end{array}$ & $\begin{array}{c}\text { Provinsi } \\
\text { DIY }\end{array}$ & Total & $\begin{array}{c}\text { Tingkat } \\
\text { Penilaian }\end{array}$ \\
\hline Pemberdayaan $\left(\mathrm{X}_{1}\right)$ & $\mathbf{7 5 , 0 1}$ & $\mathbf{7 8 , 7 1}$ & $\mathbf{7 6 , 8 6}$ & Baik \\
\hline \multicolumn{5}{|l|}{ Usaha-Usaha Pemberdayaan } \\
\hline Pendelegasian $\left(\mathrm{X}_{1.1}\right)$ & 66.38 & 71.34 & 68.86 & Cukup Baik \\
\hline Pelatihan $\left(\mathrm{X}_{1.2}\right)$ & 73.82 & 78.06 & 75.94 & Baik \\
\hline Partisipasi $\left(\mathrm{X}_{1.3}\right)$ & 81.72 & 84 & 82.86 & Baik \\
\hline Kepemimpinan $\left(\mathrm{X}_{1.4}\right)$ & 78.12 & 81.42 & 79.78 & Baik \\
\hline
\end{tabular}

Keterangan: kategori penilaian: 51 ke bawah = sangat kurang baik; di atas 51-60 = kurang baik; di atas 60-75 = cukup baik; di atas 75-90 = baik; di atas $90-100=$ amat baik.

Tabel 2. Hasil Penilaian (skor) terhadap Variabel Kompetensi PSKP.

\begin{tabular}{|c|c|c|c|c|}
\hline Variabel & $\begin{array}{l}\text { Provinsi } \\
\text { DKI }\end{array}$ & $\begin{array}{l}\text { Provinsi } \\
\text { DIY }\end{array}$ & Total & $\begin{array}{l}\text { Tingkat } \\
\text { Penilaian }\end{array}$ \\
\hline Kompetensi $\left(\mathbf{Y}_{1}\right)$ & 77,46 & 80,25 & 78,85 & Baik \\
\hline \multicolumn{5}{|l|}{ Aspek-Aspek Kompetensi } \\
\hline $\begin{array}{l}\text { Prestasi dan Tindakan } \\
\left(\mathrm{Y}_{1.1}\right)\end{array}$ & 75.24 & 78.16 & 76.70 & Baik \\
\hline $\begin{array}{l}\text { Membantu dan Melayani } \\
\left.\mathrm{Y}_{1.2}\right)\end{array}$ & 83.22 & 84.58 & 83.90 & Baik \\
\hline Mempengaruhi $\left(\mathrm{Y}_{1.3}\right)$ & 75 & 79.10 & 77.04 & Baik \\
\hline Manajerial $\left(\mathrm{Y}_{1.4}\right)$ & 80.96 & 82.90 & 81.92 & Baik \\
\hline $\operatorname{Kognitif}\left(\mathrm{Y}_{1.5}\right)$ & 76.70 & 79.76 & 78.22 & Baik \\
\hline Efektivitas Pribadi $\left(\mathrm{Y}_{1.6}\right)$ & 73.62 & 77 & 75.32 & Baik \\
\hline
\end{tabular}

Keterangan: kategori penilaian: 51 ke bawah =sangat kurang baik; di atas 51-60 = kurang baik; di atas $60-75=$ cukup baik; di atas $75-90=$ baik; di atas $90-100=$ amat baik. 
(3) Tingkat Karakteristik Internal Organisasi

Dari analisis data diperoleh hasil tentang kategori penilaian terhadap karakteristik

internal organisasi seperti disajikan pada Tabel 3 .

Tabel 3. Hasil Penilaian (skor) terhadap Variabel Karakteristik Internal Organisasi

\begin{tabular}{|l|c|c|c|c|}
\hline Variabel & $\begin{array}{c}\text { Provinsi } \\
\text { DKI }\end{array}$ & $\begin{array}{c}\text { Provinsi } \\
\text { DIY }\end{array}$ & Total & $\begin{array}{c}\text { Tingkat } \\
\text { Penilaian }\end{array}$ \\
\hline Aspek-Aspek Karakteristik Internal (X2) \\
\hline $\begin{array}{l}\text { Pendidikan Non formal } \\
\left(\mathrm{X}_{2.2}\right)\end{array}$ & 70,39 & 70,34 & 70,37 & Cukup Baik \\
\hline Masa Kerja $\left(\mathrm{X}_{2.3}\right)$ & 63.95 & 53.79 & 58.53 & $\begin{array}{c}\text { Kurang } \\
\text { Baik }\end{array}$ \\
\hline Sikap $\left(\mathrm{X}_{2.5}\right)$ & 79.75 & 82.49 & 81.21 & Baik \\
\hline $\begin{array}{l}\text { Teknologi Organisasi } \\
\left(\mathrm{X}_{2.6}\right)\end{array}$ & 67.40 & 74.17 & 71.01 & Baik \\
\hline
\end{tabular}

Keterangan: kategori penilaian: 51 ke bawah = sangat kurang baik; di atas 51-60 = kurang baik; di atas $60-75=$ cukup baik; di atas $75-90=$ baik; di atas $90-100=$ amat baik..

(4) Tingkat Motivasi PSKP

Dari analisis data diperoleh hasil, seperti disajikan tersebut pada Tabel 4. tentang kategori penilaian terhadap motivasi

Tabel 4. Hasil Penilaian (skor) terhadap Variabel Motivasi PSKP.

\begin{tabular}{|l|c|c|c|c|}
\hline Variabel & $\begin{array}{c}\text { Provinsi } \\
\text { DKI }\end{array}$ & $\begin{array}{c}\text { Provinsi } \\
\text { DIY }\end{array}$ & Total & $\begin{array}{c}\text { Tingkat } \\
\text { Penilaian }\end{array}$ \\
\hline Motivasi $\left(\mathbf{X}_{3}\right)$ & $\mathbf{7 7 , 5 2}$ & $\mathbf{7 7 , 7 3}$ & $\mathbf{7 7 , 6 2}$ & Baik \\
\hline Aspek-Aspek Motivasi $\left(\mathbf{X}_{\mathbf{3}}\right)$ & 84.52 & 86.44 & 85.48 & Baik \\
\hline Intrinsik $\left(\mathrm{X}_{3.1}\right)$ & 70.52 & 69.02 & 69.76 & Cukup Baik \\
\hline Ekstrinsik $\left(\mathrm{X}_{3.2}\right)$ &
\end{tabular}

Keterangan: kategori penilaian: 51 ke bawah =sangat kurang baik; di atas 51-60=kurang baik; di atas 60-75 = cukup baik; di atas 75-90 = baik; di atas 90-100 = amat baik.

(5) Faktor-faktor yang Mempengaruhi Kompetensi PSKP

Pemberdayaan dan motivasi PSKP merupakan faktor-faktor yang mem pengaruhi secara langsung dan nyata kompetensi PSKP pada taraf nyata 0.05 , dengan persamaan linier regresi berganda : $\mathrm{Y}_{1}$ $=-3.61+0.21 \mathrm{X}_{1}+0.76 \mathrm{X}_{2.1}+0.83 \mathrm{X}_{2.2}$ $+2.39 \mathrm{X}_{2.5}+0.94 \mathrm{X}_{2.6}+0.18 \mathrm{X}_{3}$. Keeratan hubungan dan besarnya pengaruh faktor- faktor yang mempengaruhi kompetensi PSKP ditunjukkan dengan koefisien korelasi $\mathrm{r}$ sebesar 0.77 dan koefisien determinasi $(R$ Square) sebesar 0.58 .

\section{(6) Faktor yang Mempengaruhi Motivasi PSKP}

Pemberdayaan PSKP merupakan faktor yang mempengaruhi secara langsung dan nyata motivasi PSKP pada taraf nyata 0.05. 
Pengaruh tersebut ditunjukkan dengan persamaan linier regresi tunggal : $X_{3}=0+$ $0.59 \mathrm{X}_{1}$. Derajat keeratan hubungan dan besarnya pengaruh faktor yang mempengaruhi motivasi PSKP ditunjukkan dengan koefisien korelasi $r$ sebesar 0.59 . Koefisien determinasi ( $R$ Square) sebesar 0,35.
(7) Model Pemberdayaan PSKP Terhadap Peningkatan Kompetensi PSKP

Model Pemberdayaan PSKP terhadap peningkatan kompetensi diuji dengan menggunakan analisis jalur seperti disajikan pada Gambar 2.

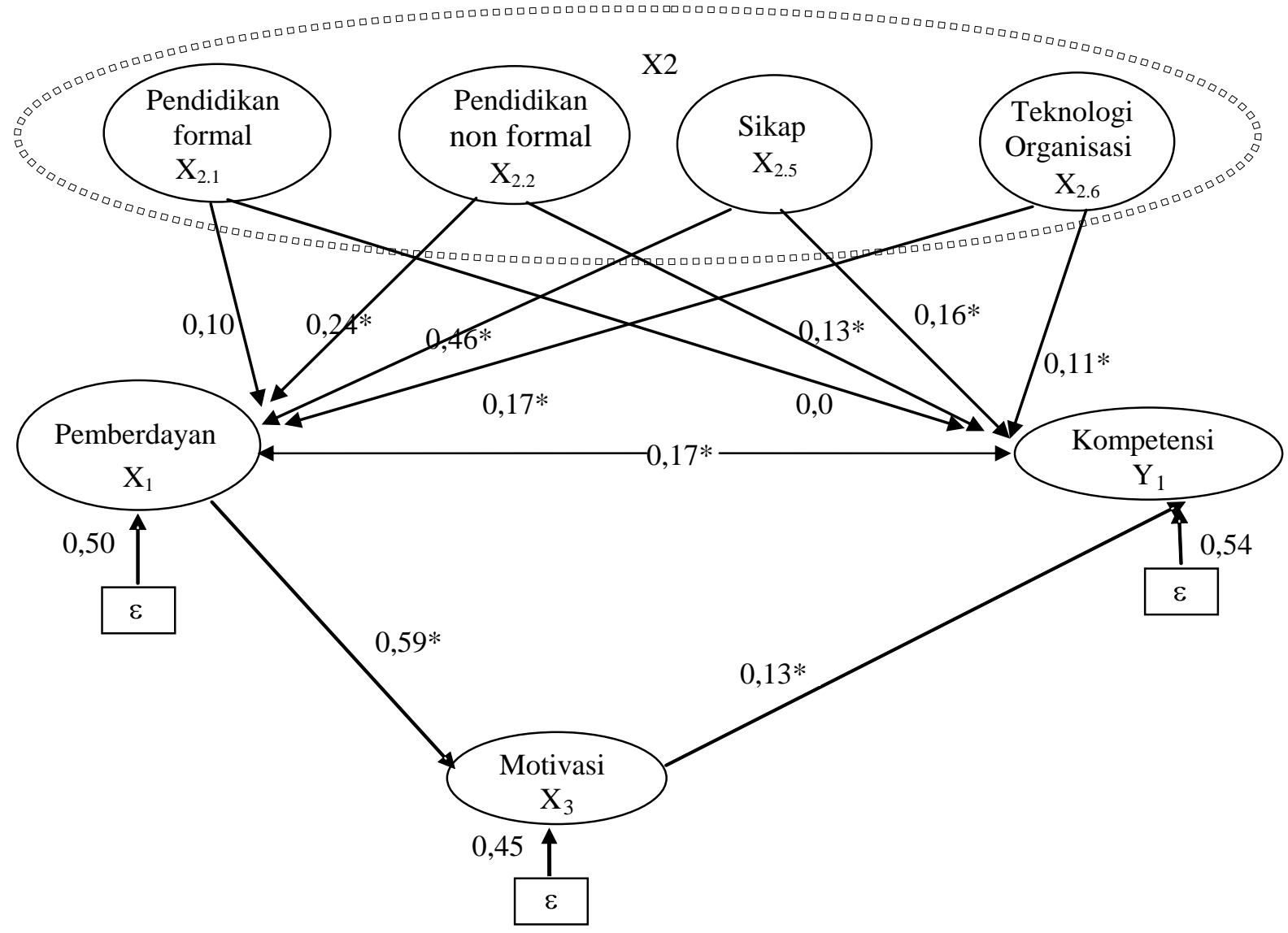

*Nyata pada taraf $10 \%$.

**Nyat pada taraf $5 \%$.

Gambar 2. Model Pemberdayaan PSKP Terhadap Peningkatan Kompetensi.

Dari Gambar 2 tersebut tampak bahwa faktor-faktor pendidikan formal, pendidikan nonformal (seminar, diskusi dan workshop) sikap dan teknologi organisasi mempengaruhi secara langsung dan nyata terhadap pemberdayaan PSKP dengan koefisien : 0.10, $0.24,0.46$ dan 0.17 . Artinya pemberdayaan terhadap PSKP akan efektif apabila aspek pendidikan non formal (seminar, diskusi dan workshop), sikap PSKP dan teknologi organisasi ditingkatkan dan dikembangkan sesuai dengan persyaratan yang diperlukan untuk jabatan struktural.

Dengan melalui pemberdayaan dan motivasi, pengaruh total pendidikan formal, pendidikan non formal (seminar,diskusi dan workshop), sikap dan teknologi organisasi terhadap kompetensi adalah: 0.1620, 0.206, 0.345 , dan 0.184. Artinya dengan meningkatkan dan mengembangkan pendidikan formal, pendidikan nonformal (seminar, diskusi dan workshop), sikap dan 
teknologi organisasi kearah pemberdayaan dan penumbuhan motivasi, maka pengembangan derajat kompetensi akan meningkat sesuai dengan persyaratan yang diperlukan untuk jabatan strukturalnya.

Faktor pemberdayaan mempengaruhi secara langsung dan nyata terhadap motivasi PSKP dengan total angka 0.59. Artinya dengan efektifnya pemberdayaan terhadap PSKP, maka motivasinya akan semakin tumbuh dan meningkat kualitasnya. Faktorfaktor pemberdayaan dan motivasi PSKP mempengaruhi secara langsung dan nyata terhadap kompetensi PSKP dengan angka: 0.21 dan 0.18 , akan tetapi dengan melalui motivasi, pengaruh total pemberdayaan terhadap kompetensi PSKP menjadi 0.316, artinya dengan efektifnya pemberdayaan terhadap PSKP dan tumbuhnya motivasi dalam diri PSKP, maka derajat kompetensinya akan semakin berkembang dan meningkat.

Rincian hasil analisis koefisien jalur disajikan dilihat pada Tabel 5.

Tabel 5. Total Koefisien Lintas Pengaruh Variabel Bebas Terhadap Variabel Tak Bebas.

\begin{tabular}{|c|c|c|c|c|}
\hline \multirow{2}{*}{$\begin{array}{c}\text { Variabel } \\
\text { Tak Bebas }\end{array}$} & \multirow[b]{2}{*}{ Variabel Bebas } & \multicolumn{3}{|c|}{ Pengaruh } \\
\hline & & Langsung & $\begin{array}{c}\text { Tak } \\
\text { Langsung }\end{array}$ & Total \\
\hline \multirow{4}{*}{$\begin{array}{l}\text { Pemberdayaan } \\
\text { PSKP (X1) }\end{array}$} & Pendidikan formal (X21) & $0.10^{*}$ & - & 0.100 \\
\hline & $\begin{array}{lcr}\begin{array}{l}\text { Pendidikan } \\
\text { (seminar non }\end{array} \text {,diskusi } & \text { formal } \\
\text { workshop) } & \text { (X22) } & \\
\end{array}$ & $0.24 * *$ & - & 0.240 \\
\hline & Sikap (X25) & $0.46 * *$ & - & 0.460 \\
\hline & Teknologi Organisasi (X26) & $0.17 * *$ & - & 0.170 \\
\hline Motivasi (X3) & Pemberdayaan PSKP (X1) & 0.59** & - & $\mathbf{0 . 5 9 0}$ \\
\hline \multirow{6}{*}{$\begin{array}{l}\text { Kompetensi } \\
\text { PSKP (Y1) }\end{array}$} & Pemberdayaan PSKP (X1) & $0.21 *$ & 0.106 & 0.316 \\
\hline & Pendidikan formal (X21) & $0.13 * *$ & 0.032 & 0.162 \\
\hline & Pendidikan non formal (X22) & $0.13 * *$ & 0.076 & 0.206 \\
\hline & Sikap (X25) & $0.20 * *$ & 0.145 & 0.345 \\
\hline & Teknologi Organisasi (X26) & $0.13 * *$ & 0.054 & 0.184 \\
\hline & Motivasi (X3) & $0.18^{* * *}$ & - & 0.180 \\
\hline
\end{tabular}

Keterangan: *Nyata pada taraf 5\%; **Sangat Nyata pada taraf $0.01 \%$.

Dengan demikian, untuk mengembangkan model peningkatan kompetensi PSKP, faktor-faktor yang perlu diperhatikan adalah: pendidikan formal, pendidikan non formal, sikap, teknologi organisasi, pemberdayaan, motivasi. Strategi yang digunakan adalah:

1. Meningkatkan jenjang pendidikan formal yang lebih tinggi dengan program bidang studi yang relevan dengan tugas dan fungsi;

2. Meningkatkan frekuensi pendidikan non- formal (seminar, diskusi dan workshop) dengan topik bahasan yang tepat dan relevan dengan tugas dan fungsi; Menumbuhkan sikap positip yang komitmen pada tugas dan fungsi;

3. Menggunakan sistem informasi yang akurat dan peralatan kerja kantor yang optimal dan memadai;

4. Melakukan pemberdayaan PSKP dengan cara mendelegasikan wewenang secara jelas dan nyata, melaksanakan diklat teknis dan diklat kepemimpinan PSKP 
berdasarkan need assessment dan berbasis kompetensi, pemberian kesempatan berpartisipasi, dan penampilan gaya kepemimpinan yang berorientasi pada hubungan manusia;

5. Menetapkan tujuan organisasi yang jelas, menciptakan lingkungan kerja yang kondusif, menetapkan pola karir pegawai yang jelas dan menetapkan sistem penggajian yang berbasis bobot jabatan dan kinerja;

6. Menetapkan persyaratan jabatan struktural dan standar kompetensi yang jelas sebagai acuan dalam pengangkatan pejabat struktural dengan menggunakan metode assessment centre.

\section{Kesimpulan}

Berdasarkan kerangka teori dan hasil analisis data di atas, diambil kesimpulan sebagai berikut :

(1) Sikap, pemberdayaan, motivasi dan kompetensi PSKP belum optimal karena belum mencapai tingkat kategori sangat baik. Demikian pula dengan intensitas pendidikan nonformal (seminar, diskusi dan workshop) dan pemanfaatan teknologi organisasi, serta pengalaman kerja PSKP.

(2) Faktor-faktor determinan yang mempengaruhi kompetensi PSKP adalah pendidikan formal yang tepat, intensitas pendidikan non formal (seminar, diskusi dan workshop) yang tepat dan relevan, penumbuhan dan pengembangan sikap positif, penggunaan teknologi organisasi yang akurat, memadai dan optimal, intensitas pemberdayaan serta keefektivan dalam mengembangkan motivasi PSKP.

(3) Faktor determinan yang mempengaruhi motivasi adalah intensitas pemberdayaan PSKP yang tepat.

(4) Perpaduan yang tepat dari faktor-faktor yang secara nyata mempengaruhi pemberdayaan, kompetensi dan motivasi merupakan model Pemberdayaan PSKP untuk peningkatan kompetensi.

\section{Rujukan}

Badan Kepegawaian Daerah Propinsi Jawa Tengah. 2002. Wacana Pengembangan Manajemen Kepegawaian Daerah. Semarang: Pustaka Baru.

Cohen, J., dan P.Cohen, 1983. Applied Multiple Regression/Correlation for the Behavioral Sciences. London: Lawrence Erlbaum Associates, Publishers Hillsdae New Jersey.

Djohan, D.J, Rustriningsih, dan Pompy. 2002. Kebijakan Perubahan Otonomi Daerah. Seri Kertas Kerja: volume II Nomer 03 : halaman 1-23.

Ferdinand, A. 2000. Structural Equation Modeling Dalam Penelitian Manajemen. Semarang: Badan Penerbit Universitas Diponegoro.

Kerlinger, F.N. 2000. Asas-Asas Penelitian Behavioral. (Terjemahan dari: Landung R Simatupang). Koesoemanto, H. L., editor. Yogyakarta: Gadjah mada University Press.

Sevilla, C.G., J.A. Ochave., T.G, Punsalan., B.P. Regala., dan G.G. Uriarte. 1993. Pengantar Metode Penelitian. (Terjemahan dari: Alimuddin Tuwu). Jakarta: UI Press.

Singarimbun M., dan S.Effendi. 1995. Metode Penelitian Survai. Diedit oleh M.Singarimbun. Jakarta: PT Pustaka LP3ES.

Spencer Jr. L.M., dan S.M. Spencer , 1993. Competence at Work. Canada: John Wiley and Sons Inc.

Sudjana. 2000. Statistika. Jilid I . Bandung: Penerbit Transito. . 1996. Metoda Statistika. Bandung: Penerbit Transito. 
Djoko Sutrisno, Sumardjo, Pang S. Asngari, Soedijanto Padmowihardjo dan Prabowo Tjitropranoto/ Jurnal Penyuluhan Juni 2006, Vol. 2, No. 2

Sumardjo.1999. "Transformasi Model

Penyuluhan Pertanian Menuju

Pengembangan Kemandirian

Petani”. Disertasi. Bogor: Institut

Pertanian Bogor. 